Konstruktivisme : Jurnal Pendidikan dan Pembelajaran

Vol. 11, No. 02, Juli, 2019, e-ISSN: 2442-2355

FKIP, Universitas Islam Balitar

Website: https://ejournal.unisbablitar.ac.id/index.php/konstruktivisme/index

Email: konstruktivisme@unisbablitar.ac.id

\title{
REDEFINING LEARNING PROCESS THROUGH FLIPPED CLASSROOM
}

\author{
Adin Fauzi ${ }^{(1)}$ \\ Department of Primary School Teacher Education, Faculty of Teacher Training \\ and Education, Universitas Islam Balitar Blitar \\ Jl. Majapahit No. 04 Blitar \\ E-mail: adinfauzi@unisbablitar.ac.id
}

\section{ABSTRACT}

This study addresses the implementation of the flipped classroom in redefining the traditional learning process in higher education. The data were collected by observing the learning process of Advanced Listening course, which was set up in a flipped classroom mode. The data of observation showed that the steps in the flipped classroom were as follows: (1) learning the materials (beyond the classroom); (2) taking notes and preparing questions (beyond the classroom); (3) presenting the materials (inside the classroom); and (4) discussing the materials (inside the classroom). The findings suggest that educators should start flipping the classroom since it provides a lot of educational benefits.

Keywords: redefinition, learning process, flipped classroom 
Adin Fauzi(1). 2019. Redefining Learning Process through Flipped Classroom Konstruktivisme : Jurnal Pendidikan dan Pembelajaran, 11 (2): 114-122

\section{ABSTRAK}

Penelitian ini membahas implementasi flipped classroom dalam inovasi pembelajaran pada institusi pendidikan tinggi. Data dalam penelitian ini didapat dengan mengamati proses pembelajaran mata kuliah Advanced Listening, yang didesain dalam bentuk flipped classroom. Data observasi menunjukkan bahwa langkah-langkah dalam flipped classroom adalah sebagai berikut: (1) mempelajari materi (di luar kelas); (2) membuat catatan dan menyiapkan pertanyaan (di luar kelas); (3) mempresentasikan materi (di dalam kelas); dan (4) mendiskusikan materi (di dalam kelas). Hasil penelitian menunjukkan bahwa pendidik sebaiknya mengadopsi flipped classroom karena model ini memberikan banyak manfaat dalam proses pembelajaran.

Kata Kunci: inovasi, proses pembelajaran, flipped classroom

\section{INTRODUCTION}

Flipped classroom is a reform in educational practices. It has been gaining acceptance among educators worldwide. To understand the nature of the flipped classroom, we need to refer to the pioneers of the learning model. As one of the pioneers, Bergmann \& Sams (2014) began flipping their classroom in 2007. They flipped their classroom by adopting teacher-created video as an instructional tool. However, when asked to define what exactly the flipped classroom is, it has been difficult to answer since it can vary in each level of education. Today, though, as the flipped classroom topic escalates among educators and researchers, we understand its concept through plentiful published studies informing the definition, practices, advantages, disadvantages, development of the flipped classroom model, etc. In the realm of language learning, several studies centering on the topic of flipped classroom also have existed; for instance, Webb, Doman, \& Pusey (2014); Evseeva \& Solozhenko (2015); Soliman (2016); and Chilingaryan \& Zvereva (2017).

In practice, the flipped classroom is strongly linked with learning theories. According to Eppard \& Rochdi (2017), there are at least three learning theories allied with the flipped classroom namely Bloom's taxonomy, constructivism, and mastery learning. To begin with, Bloom's taxonomy containing the levels of learning is relevant to the flipped classroom in terms of the transmission and assimilation of information. The lower learning levels such as remembering and understanding are performed outside the classroom 
through the transmission of information. Meanwhile, the higher levels including applying, analyzing, evaluating, and creating are performed inside the classroom through the assimilation of information with teachers' mentoring or guidance. In constructivism theory, especially in language learning, it is stated that learning is a social activity (Hein, 1999, in Fauziati, 2016). In this context, learning is associated with some connections with teachers, peers, families, etc. In other words, students are unable to learn by themselves. They need guidance from more capable persons either peers or teachers. This concept is referred to as the zone of proximal development (Vygotsky, 1978). In reference to the flipped classroom, students are provided with continuous guidance either outside the classroom through mobile learning, or inside the classroom through the teachers' assistance. In addition to Bloom's taxonomy and constructivism, mastery learning is also linked to the flipped classroom. In mastery learning, every student must learn common, well-structured objectives. If a student does not master an objective, remediation is necessary. This concept can be applied in the flipped classroom. As Bergmann \& Sams (2014) suggested, the flipped classroom allows for differentiation. Thus, teachers can individualize their instruction by considering each student's need.

In addition to allowing teachers to individualize instruction, the flipped classroom also leads students to learn at their own pace (Bergmann \& Sams, 2014; Chilingaryan \& Zvereva, 2016; Du, Fu, \& Wang, 2014; Soliman, 2016). The atmosphere of learning process is more welcoming, comfortable, and motivating when a traditional classroom is flipped (Bergmann \& Sams, 2014; Chilingaryan \& Zvereva, 2016). Besides, teachers can enhance their interaction with students in the flipped classroom (Bergmann \& Sams, 2014; Chilingaryan \& Zvereva, 2016). The benefits offered by the flipped classroom indicate that the flipped classroom is an effective and promising mode of learning.

One of the keys in conducting a flipped classroom is the availability technology. Educational technology is no longer a new issue. Instead, many educators start adopting technology in instructional practices. To address this issue, it is worth analyzing how far educators use technology in teaching, and how educational technology impacts the learning process. With regard to this, Puentedura (2009) developed an analysis model namely the SAMR model. The SAMR stands for Substitution, Augmentation, Modification, and Redefinition. At Substitution, technology acts as a direct tool substitute, with no functional change; at Augmentation, technology acts a direct tool substitute, with functional change; at Modification, technology allows for significant task redesign; and at Redefinition, technology allows for the creation of new tasks, previously inconceivable (Puentedura, 2019). This study specifically discusses the implementation of the flipped classroom as a representation of the Redefinition level. The redefinition level is worth 
analyzing as not many educators reach this level. A study done by Fauzi, Rochsantiningsih, \& Tarjana (2018) found that amidst the three teachers being studied, only one teacher who achieved the Redefinition level by creating an exceptional project; that is, student-created video game.

Regarding the flipped classroom in English learning, several studies have been carried out concerning the advantages of a flipped classroom (Chilingaryan \& Zvereva, 2016); the challenges in conducting a flipped classroom (Evseeva \& Solozhenko, 2015); and higher students' perception of the flipped classroom (Webb et al., 2014). Compared to those studies, this study is different in terms of the analysis of findings. This study describes the implementation of the flipped classroom in higher education based on the SAMR model. Among the four levels of the SAMR model, this study concerns only the Redefinition level as it is the highest level of technology integration in learning process. The significance of this study is that it provides educators with the report of the flipped classroom in higher education; therefore, educators (lecturers) will be well-informed regarding the techniques of redefining the learning process.

\section{METHOD}

This research adopted a qualitative approach. It was conducted during the Advanced Listening course at Balitar Islamic University. The course was offered to 23 students of the fourth semester. The students were enrolled in English Education Department. The data were collected in the odd semester of 2018/2019 academic year. The principal method for collecting the data was by observing the learning process. Five teaching sessions designed in the flipped classroom model were thoroughly observed to figure out the effective implementation of the flipped classroom. Following Miles \& Huberman (1994), the data were analyzed by doing three steps namely reducing the entire data, displaying the data, and drawing conclusion.

\section{RESULT}

Before conducting the flipped classroom, the instructor firstly divided the students into some groups of presentation. It was to manage which students in one session would perform in the classroom. 


\section{Outside-the-classroom Activities}

This study was conducted during the teaching and learning of Advanced Listening Course. In this case, relevant materials in the form of video or audio should be carefully prepared. For the purpose of beyond the classroom activities, TED videos were adopted. TED contains of thousands of videos so the students can choose their own videos based on their preferences. There were some activities the students must perform beyond the classroom as follows.

\section{Finding videos}

In this study, the initial step in the flipped classroom was that the students must explore TED talk website (www.ted.com/talks). Each student should download a video and understand the video. Once a student had downloaded the video, he/she should immediately share the link of the video with other students via Google Classroom. This way, all the students watched the video whose content would be used as a discussion material in the classroom.

\section{Taking notes}

After all the students received the link of the video, they should take notes. In particular, they should summarize the content of the video, and write a short opinion of the video. This task would prepare them to get involved in the classroom discussion, and it was one of the assessment criteria.

\section{Preparing questions}

In addition to getting the gist of the video, the students must also prepare questions. It was intended to raise their confidence level since they were often reluctant to ask questions in the classroom. The students must prepare at least one question to be asked in the classroom.

\section{Inside-the-class Activities}

Once the students had prepared anything either summary, opinion, or question, they attended the classroom with readiness to learn. There were some activities performed in the classroom as follows.

\section{Presenting the Video}

The initial activity in the classroom was that a student, who was in charge of presenting, performed in front of the class to share with the class what they learned from the video. In this case, he/she should be the one who most understood the content since the video being discussed was his/her 
choice. The student should be able to answer questions raised by other students.

\section{Generating a Classroom Discussion}

In the flipped classroom, the students came to the classroom with ideas. They already had a picture of what would be discussed in the classroom. To check whether they learned the video, the instructor initially invited them to share their thoughts related to the video in a classical discussion. Since they learned the materials in advance, many of them could contribute to the discussion. In addition, the students could raise questions they had prepared. In fact, not all the questions could be well answered by the presenter. The main problem was their limited speaking skill. When it happened, the instructor helped the presenter to deliver what they wanted to say. Other students were also invited to help answer the questions. This way, the classroom situation was enjoyable. The instructor was no longer the central figure in the classroom, being the most knowledgeable person. In other words, the learning process was shifted from teacher-centered to studentcentered learning thanks to the flipped classroom. To summary, Figure 1 depicts the clear steps in conducting a flipped classroom in higher education on the subject of Advance Listening course.

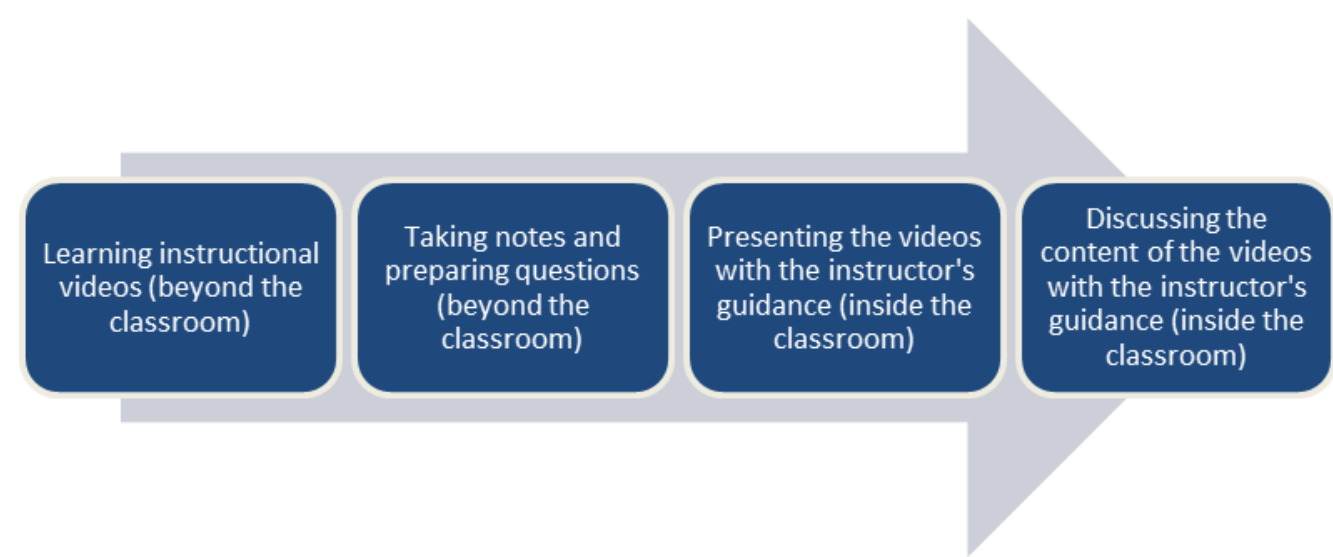

Figure 1. The Steps of Flipped Classroom in Advanced Listening Course

\section{DISCUSSION}

This study revealed that the flipped classroom was applicable in teaching Advanced Listening Course. It generally consisted of some steps including finding instructional videos and comprehending the videos beyond the classroom, and discussing the content of the videos inside the classroom. 
This practice remains extraordinary for most educators since they used to teach in the class by delivering the materials and subsequently giving homework in the form of worksheet.

Based on the findings, the flipped classroom was beneficial in some aspects. First, the students learned at their own pace (Bergmann \& Sams, 2014). The students watched the video many times till they understood the content. This practice is somewhat difficult to perform in the classroom due to the time restriction.

Second, the students received assistance on a difficult course (Bergmann \& Sams, 2014). Advanced Listening is surely difficult since it is the highest level of listening course taught in the university. In fact, most of the students had a problem in listening skill at advanced level. In the flipped classroom, they did not need to comprehend the whole content of the video. Instead, they prepared questions related to the content before attending the class, and asked the questions inside the class.

Third, each student received special attention (Bergmann \& Sams, 2014). It was evident that each student was given a chance to find their own videos based on their preferences. During the process of finding the videos, some students encountered technical problems. They reached the instructor via WhatsApp and got solutions. When they were presenting the video in front of the class, they also got individual assistance from the instructor either in presenting or answering questions.

In addition to the abovementioned benefits, the flipped classroom also enhanced the students' motivation and confidence. It was evident from their enthusiasm in finding videos, and their courage in either presenting the video or asking questions. More importantly, the flipped classroom was able to redefine the learning process previously inconceivable; that is, by allowing students to experience a variety of learning activities either inside the classroom or beyond the classroom, along with the use of diverse technologies.

\section{CONCLUSION}

The flipped classroom was found valuable to redefine the learning process. The redefined learning process enabled the students to collaborate with other students and teachers on a difficult course. All the students learned and discussed an instructional video with the teachers' guidance in the classroom. The students were also accompanied by some tools including TED videos, Google Classroom, and WhatsApp either to find resources, ask for help, or communicate their ideas. These practices indicate that the learning process achieved Redefinition level, as suggested by Puentedura (2009). Teachers can use this research as the reference in conducting a flipped 
classroom. The step-by-step procedures of the flipped classroom in this study will assist teachers in flipping the traditional classroom.

\section{SUGGESTION}

Regarding the findings of this study, educators are suggested to start flipping their classrooms since it is effective to create a student-centered learning, as demanded by the curriculum. However, it remains to be further clarified whether the findings could be applied to other courses or other education levels. Besides, future work can also cover the development of flipped classroom guidelines in a specific course.

\section{BIBLIOGRAPHY}

Bergman, J., \& Sams, A. (2014). The flipped classroom, CSE, 17(3), 24-27.

Chilingaryan, K., \& Zvereva, E. (2016). Methodology of flipped classroom as a learning technology in foreign language teaching. Procedia - Social and Behavioral Science, 237(2017), 1500-1504.

Du, S., Fu, Z., \& Wang, Y. (2014). The flipped classroom-advantages and challenges. International Conference on Economic Management and Trade Cooperation, 17-20.

Eppard, J., \& Rochdi, A. (2017). A framework for flipped learning. 13 th International Conference Mobile Learning.

Evseeva, A., \& Solozhenko, A. (2015). Use of flipped classroom technology in language learning. Procedia - Social and Behavioral Science, 206(2015), $205-209$.

Fauzi, A., Rochsantiningsih, D., \& Tarjana, S. S. (2018). ICT acceptance of Indonesian teachers in TEFL: A case study of senior high school EFL teachers (Unpublished master's thesis). Sebelas Maret University, Surakarta.

Fauziati, E. (2016). Principles of foreign language teaching, learning, and researching. Surakarta: Era Pustaka Utama

Miles, M. B., \& Huberman, A. M. (1994). Qualitative data analysis (2nd.). London: Sage Publications. 
Adin Fauzi(1). 2019. Redefining Learning Process through Flipped Classroom Konstruktivisme : Jurnal Pendidikan dan Pembelajaran, 11 (2): 114-122

Puentedura, R. (2009). Technology, change, and process. Retrieved from http://hippasus.com/resources/actem2009/TechnologyChangeProcess. pdf

Soliman, N, A. (2016). Teaching English for academic purposes via the flipped learning approach. Procedia - Social and Behavioral Science, 232(2016), 122-129.

Vygotsky, L. (1978). Mind in society. Cambridge MA: Harvard University Press.

Webb, M., Doman, E., \& Pusey, K. (2014). Flipping a Chinese university EFL course: What students and teachers think of the model. The Journal of ASIA TEFL, 11(4), 53-87. 